\title{
MIR24-1 Pre-miRNA
}

National Cancer Institute

\section{Source}

National Cancer Institute. MIR24-1 Pre-miRNA. NCI Thesaurus. Code C82717.

MIR24-1 pre-miRNA is an oligoribonucleotide that is encoded by the human MIR24-1

gene and is involved in the regulation of gene expression. 